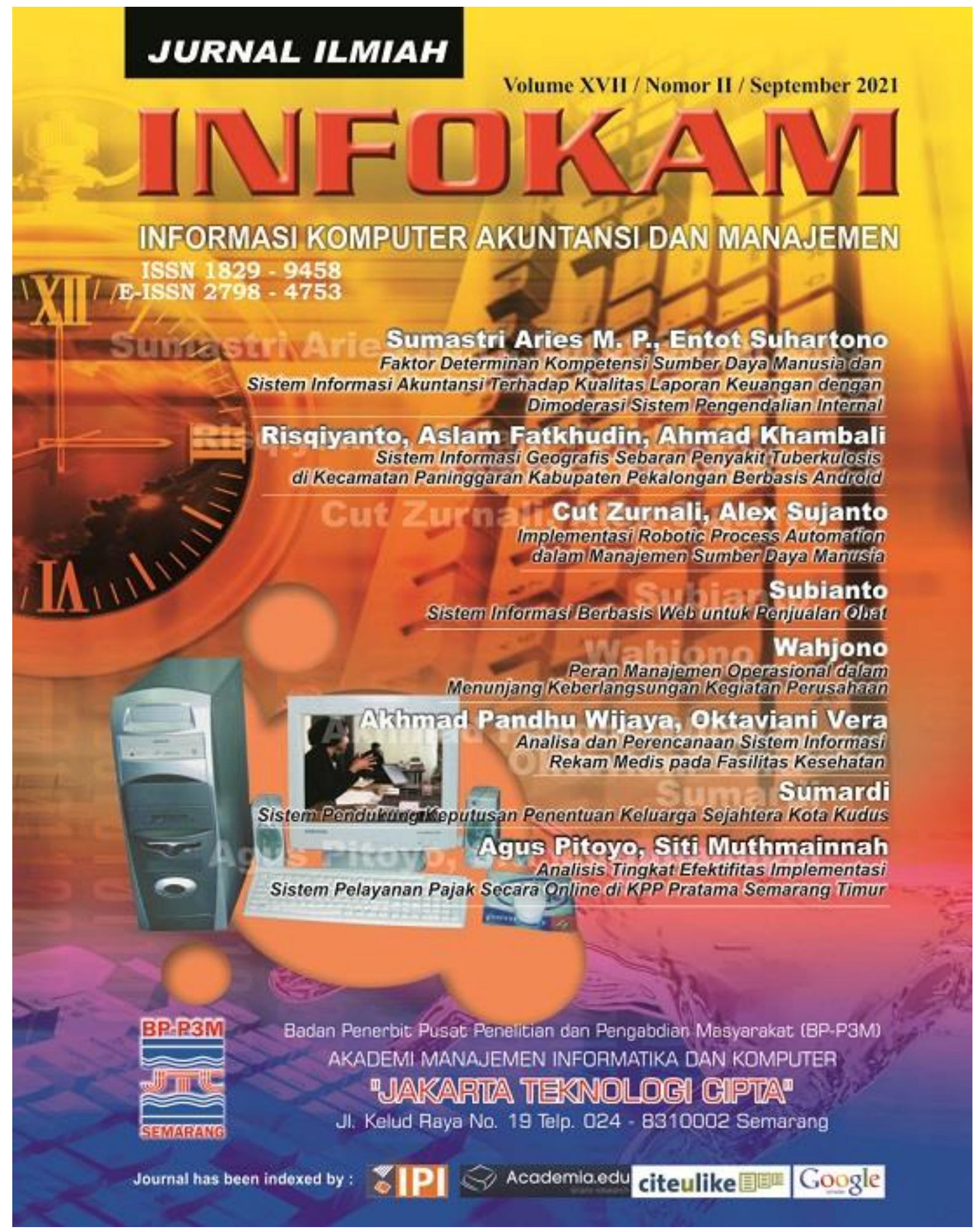


INFORMASI KOMPUTER AKUNTANSI DAN MANAJEMEN

ISSN 1829 - 9458

E-ISSN 2798 - 4753

SK DIREKTUR AMIK "JTC" SEMARANG

NO. 6305/AMIKJTC/D/IX/2020

Penasehat : Dr. Alex Sujanto, SE, S.Pd, MM. (Direktur)

Pengarah : Kristiawan Nugroho, M.Kom (Pudir I)

Muhamad Danuri, M.Kom (Pudir III)

Penanggung Jawab : Sumardi, S.Kom, M.Kom (Ka Progdi KA)

Subianto, S.Kom, M.Kom (Ka.Progdi MI)

Ketua Dewan Redaksi

Wahjono, SE, M.Si (Ketua Editor)

Sekretaris Editor

Anton Sujarwo, M.Si

Bendahara

Agus Pitoyo, M.Si

Anggota Dewan Editor

Subianto, M.Kom

Sumardi, M.Kom

Dr. Heru Sulistyo, SE, MSI ( STIE Dharmaputra Semarang)

Agus Prasetyo Utomo, MM., M.Kom (Univ. Stikubank Semarang)

Ira Setiawati, SE, M.Si (Univ. PGRI Semarang)

Eko Riyanto, S.Pd, M.Kom (STMIK Himsya Semarang)

Editor Teknis Dan Pelaksana

Sugeng Murdowo, S.T, S.Kom, M.Kom

Dr. Alex Sujanto, SE, S.Pd, MM

Mitra Bestari Peer Reviewer

Komputer

Daniel Alfa Puryanto, M.Kom (STMIK AKI Pati)

Aslam Fathkudin, M.Kom (Univ. Muh. Pekajangan Pekalongan)

Entot Suhartono, M.Kom (Univ. Dian Nuswantoro)

Fata Nida'ul Khasanah, M.Eng (Univ. Bhayangkara Jakarta Raya)

Noor Azizah, S.Kom, M.Kom (Univ. Islam Nahdatul Ulama Jepara)

\section{Akuntansi}

Dr. Heru Sulistiyo, M.Si, Akt (STIE Dharmaputra Semarang)

Arini Novandalina, M.Si (STIE Semarang)

Manajemen

Prof. Dr. Amron, SE. MM (Univ. Dian Nuswantoro Semarang)

Entot Suhartono, M. Kom (Univ. Dian Nuswantoro Semarang)

\section{Section Editor}

Subianto, S.Kom, M.Kom

Jurnal Ilmiah INFOKAM terbit minimal setiap 6 bulan sekali $(2 \mathrm{X}$ dalam setahun, bulan Maret \& September ) oleh AMIK "JTC" Semarang dengan maksud sebagai media informasi tentang Komputer, Akuntansi dan Manajemen bagi Sivitas Akademika pada khususnya dan masyarakat pada umumnya.

Alamat Redaksi / Penerbit :

Badan Penerbit Pusat Penelitian dan Pengabdian Masyarakat (BP-P3M)

AKADEMI MANAJEMEN INFORMATIKA DAN KOMPUTER

"JAKARTA TEKNOLOGI CIPTA"

Jl. Kelud Raya No. 19 Telp. 024 - 8310002 Semarang www.amikjtc.com/jurnal, email : infokam.amikjtc@gmail.com 


\section{INFORMASI KOMPUTER AKUNTANSI DAN MANAJEMEN \\ ISSN 1829 - 9458 \\ E-ISSN 2798 - 4753}

\section{DAFTAR ISI}

Faktor Determinan Kompetensi Sumber Daya Manusia dan Sistem Informasi Akuntansi Terhadap Kualitas Laporan Keuangan dengan Dimoderasi Sistem Pengendalian Internal

Sumastri Aries M. P., Entot Suhartono

Sistem Informasi Geografis Sebaran Penyakit Tuberkulosis di Kecamatan Paninggaran Kabupaten Pekalongan Berbasis Android

Risqiyanto, Aslam Fatkhudin, Ahmad Khambali

Implementasi Robotic Process Automation Dalam Manajemen Sumber Daya Manusia

Cut Zurnali, Alex Sujanto

Sistem Informasi Berbasis Web untuk Penjualan Obat

Subianto

Peran Manajemen Operasional dalam Menunjang Keberlangsungan Kegiatan Perusahaan

Wahjono

Analisa dan Perencanaan Sistem Informasi Rekam Medis pada Fasilitas Kesehatan

Akhmad Pandhu Wijaya, Oktaviani Vera

Sistem Pendukung Keputusan Penentuan Keluarga Sejahtera Kota Kudus Sumardi

Analisis Tingkat Efektifitas Implementasi Sistem Pelayanan Pajak Secara Online di KPP Pratama Semarang Timur Agus Pitoyo, Siti Muthmainnah 


\title{
Sistem Informasi Geografis Sebaran Penyakit Tuberkulosis di Kecamatan Paninggaran Kabupaten Pekalongan Berbasis Android
}

\author{
Risqiyanto', Aslam Fatkhudin ${ }^{2}$, Ahmad Khambali ${ }^{3}$ \\ Email: risqiyanto@umpp.ac.id ${ }^{\mathbf{1}}$, aslamfatkhudin@umpp.ac.id ${ }^{2}$, khambali@umpp.ac.id ${ }^{3}$ \\ Diploma Tiga Manajemen Informatika \\ Universitas Muhammadiyah Pekajangan Pekalongan
}

\begin{abstract}
Abstrak
Tuberkulosis merupakan penyakit menular yang bisa menginfeksi seseorang ke orang lainnya yang disebabkan oleh bakteri Mycrobacterium Tuberculosis. Penyakit ini tidak hanya menular ke orang yang berusia produktif (15-45) saja, tetapi remaja atau anak-anak dibawah 15 tahun juga dapat terinfeksi bakteri tersebut. Setiap tahunnya ditemukan kasus baru di Indonesia seperti di wilayah kerja Puskesmas Paninggaran Kecamatan Paninggaran. Puskesmas serta Rumah Sakit merupakan fasilitas kesehatan bagi masyarakat yang memiliki sarana dan prasarana untuk menentukan seberapa besar cakupan angka kesehatan untuk masyarakat. Dari analisa tersebut, dapat ditemukan kendala yang harus di hadapi yaitu cara memberi informasi kepada masyarakat tentang sebaran penyakit Tuberkulosis di Kecamatan Paninggaran. Hal inilah yang mendasari penelitian ini untuk menciptakan sebuah aplikasi Sistem Informasi Geografis sebaran penyakit tuberkulosis di Kecamatan Paninggaran berbasis android dengan menu-menu yang bermanfaat bagi masyarakat luas serta mudah digunakan. Metode yang digunakan dalam penelitian ini adalah Metode Waterfall. Hasil akhir dari penelitian ini berupa "Sistem Informasi Geografis Sebaran Penyakit Tuberkulosis di Kecamatan Paninggaran" dalam bentuk aplikasi android bagi masyarakat dan Website bagi admin yaitu petugas Puskesmas Paninggaran,sehingga dapat mempermudah penyaluran informasi tentang Tuberkulosis kepada masyarakat dan dinas kesehatan terkait, aplikasi ini juga dapat menampilkan peta sebaran penyakit Tuberkulosis, lokasi tempat tinggal pasien Tuberkulosis, jumlah data kasus Tuberkulosis dan berita edukasi tentang penyakit Tuberkulosis.
\end{abstract}

Kata Kunci: Sistem Informasi Geografis, Persebaran Penyakit Tuberkiulosis, dan Android

\begin{abstract}
Tuberculosis is an infectious disease that can infect one person to another caused by the bacterium Mycobacterium tuberculosis. This disease is not only transmitted to people of productive age (15-45), but teenagers or children under 15 years can also be infected with the bacteria. Every year new cases are found in Indonesia, such as in the work area of the Paninggaran Health Center, Paninggaran District. Public Health Centers and Hospitals are health facilities for the community that have the facilities and infrastructure to determine how large the coverage of health figures for the community is. From this analysis, it can be found the obstacles that must be faced, namely how to provide information to the public about the spread of Tuberculosis in Paninggaran District. This is what underlies this research to create an Android-based Geographic Information System application for the distribution of tuberculosis in Paninggaran District with menus that are useful for the wider community and easy to use. The method used in this research is the Waterfall Method. The final result of this study is a "Geographical Information System for the Distribution of Tuberculosis in Paninggaran District" in the form of an android application for the community and a website for admins, namely Paninggaran Health Center officers, so that it can facilitate the distribution of information about Tuberculosis to the community and related health services, this application can also displays a map of the distribution of Tuberculosis disease, the location of where Tuberculosis patients live, the number of Tuberculosis case data and educational news about Tuberculosis disease.

Keywords: Geographic Information System, Distribution of Tuberculosis, and Android
\end{abstract}




\section{Pendahuluan}

Tuberkulosis merupakan penyakit menular yang disebabkan oleh bakteri Mycobacterium Tuberculosis yang penularannya melalui droplet atau percik renik dahak dari penderita TB positif. Bakteri penyebab Tuberkulosis ditemukan oleh Robert Koch pada tanggal 2 Maret 1882 silam, dan sampai saat ini proses penelitian masih berlanjut, karena tidak sedikit menelan banyak korban jiwa yang meninggal. Tahun 2014 WHO mengumumkan bahwa wabah Tuberkulosis ini mejadi penyebab angka kematian urutan ke 10 di dunia, sehingga sampai saat ini penanggulangan penyakit TB masih mejadi prioritas utama di dunia untuk menuju Sustainability Development Goals atau Tujuan Pembangunan Berkelanjutan (Daniati;, 2021).

Di Indonesia sendiri penyakit menular akibat perilaku dan lingkungan yang tidak sehat masih menjadi perhatian pemerintah. Tuberkulosis penyakit menular yang menginfeksi masyarakat di banyak negara terutama negara berkembang seperti di Negara Indonesia. Pada Tahun 2020 situs tbindonesia.or.id menuliskan data dan situasi Tuberkulosis di Indonesia sebagian kasus (67\%) terjadi pada usia produktif (15-45) dan $9 \%$ usia anak kurang dari 15 Tahun, di dunia 10 juta orang menderita TBC dan menyebabkan 1,2 juta meninggal, Indonesia merupakan negara yang tinggi dengan angka kasus TBC mencapai 845.000 dengan angka kematian 98.000 atau setara 11 orang/jam (Daniati;, 2021).

Di situs data.pekalongankab.go.id, tercatat bahwa angka kasus TB pada tahun 2018 yaitu sebanyak 7.303, di Kecamatan Paninggaran sendiri angka kasus TB per Januari 2020 sampai dengan Juni 2021 sebanyak 61 kasus dengan pengobatan awal bulan Januari 2020, artinya setiap tahun angka Tuberkulosis selalu ada kasus penambahan, dimana kasus TB tersebut ditinjau dari beberapa faktor, seperti faktor kesehatan lingkungan, cakupan rumah sehat, kepadatan penduduk, ketinggian wilayah. Maka dari itu, peran pemerintah sangat berpengaruh terhadap cakupan angka sehat dari wabah ini, kesadaran masyarakat akan pentingnya menjaga kesehatan perlu ditingkatkan dan di prioritaskan karena bakteri ini dapat memicu organ dan penyakit lain seperti DM serta HIV sedangkan orang berusia 15 kebawahpun dapat terinfeksi bakteri ini.

Puskesmas dan Rumah Sakit merupakan fasilitas kesehatan bagi masyarakat, sarana prasarana menentukan seberapa besar cakupan angka kesehatan di masyarakat luas. Teknologi juga berperan aktif dan penting dalam menyambungkan suatu informasi dari berbagai sektor, seperti sektor kesehatan dapat memanfaatkan Tekhnologi sebagai edukasi masyarakat luas supaya kesadaran akan menjaga kesehatan lebih tinggi.

Dari uraian permasalahan di atas itulah yang melatarbelakangi penulis membuat penelitian dengan judul "Sistem Informasi Georafis Persebaran Penyakit Tuberkulosis di Kecamatan Paninggaran berbasis Android" yang diharapkan dapat mempermudah penyaluran informasi kepada masyarakat dan dinas kesehatan terkait serta dapat menampilkan peta persebaran penyakit Tuberkulosis secara rinci dan detail. Selain itu penulis juga akan menampilkan lokasi tempat tinggal, umur, jenis kelamin pasien Tuberkulosis di kecamatan Paninggaran, dimana aplikasi tersebut dapat diakses dengan jaringan internet diantaranya bekerja sama dengan Kantor Kelurahan dan Puskesmas Paninggaran.

\section{Landasan Teori}

\section{a. Sistem Informasi}

Sistem Informasi merupakan gabungan dua kata yang masing-masing memiliki definisi tersendiri. Sistem adalah kumpulan elemen yang saling berinteraksi untuk mencapai tujuan tertentu. Sedangkan Informasi adalah data yang diolah menjadi lebih berguna bagi yang menerimanya (Sutabri, 2012). Jadi dapat diambil kesimpulan bahwa Sistem Informasi adalah kumpulan elemen atau data yang saling berinteraksi yang dapat diolah menjadi sesuatu yang lebih berguna.

\section{b. Sistem Informasi Geografis}

Sama halnya dengan Sistem Informasi di atas, Sistem Informasi Geografis (SIG) juga terdiri dari tiga kata, yaitu Sistem, Informasi dan Geografis. Mengenai definisi dari Sistem Informasi, sudah dijelaskan pada point sebelumnya, sedangkan Geografis adalah sesuatu yang berhubungan dengan permukaan bumi. Jadi Sistem Infromasi Gegorafis adalah suatu sistem informasi yang berhubungan dengan permukaan bumi yang diolah dengan media komputer (Prahasta, 2002). 


\section{c. Website}

Website adalah kumpulan beberapa halaman yang didalamnya bisa berupa teks, gambar (baik statis maupun bergerak/animasi), suara dan video yang saling berhubungan yang dapat diakses melalui jaringan internet (Bekti, 2015).

\section{d. Android}

Android merupakan Sistem Operasi (Operating System) yang dikembangkan oleh Google yang bersifat Open Source sehingga para programmer dapat membuat aplikasi sendiri yang dapat dijalankan di Sistem Operasi (SO) Android tersebut. Biasanya SO Android ini ditanamkan pada perangkat mobile misalnya smartphone (Susanto, 2018).

\section{e. Google Map}

Google Map adalah peta dunia digital yang dikembangkan/dibuat oleh Google. Aplikasi ini sangat populer, disamping menjadi rujukan para pencari jalur peta, aplikasi ini juga dapat diterapkan oleh programmer web atau mobile di website atau aplikasi mobilenya dengan menggunakan library Google Maps API yang berbentuk JavaScript (Yusro, 2013).

\section{f. Basis Data}

Sesuai dengan namanya, Basis Data adalah kumpulan data. Basis data tidak hanya sebagai kumpulan data saja, tetapi data-data tersebut saling berinteraksi, sehingga data tersebut dapat disimpan, dimanipulasi serta diakses oleh pengguna (Nugroho, 2011).

\section{g. DBMS}

DBMS adalah kependekan dari Database Management System yaitu suatu sistem basis data berbasis komputer yang dibuat secara khusus untuk memudahkan para pemakai dalam mengatasi kelemahan sistem pemrosesan data berbasis berkas (Kadir \& Triwahyun, 2013).

\section{h. Flowchart}

flowchart adalah bagan alir yang dibentuk dari beberapa simbol-simbol tertentu yang menggambarkan algoritma bagaimana suatu sistem itu berjalan (Amsyah, 2001).

i. DFD

DFD (Data flow diagram) merupakan diagram arus data yang menggambarkan kumpulan komponen sistem baik sistem komputerisasi, manual atau bahkan gabungan keduanya yang saling berinteraksi sesuai dengan aturan mainnya (Sutabri, 2012).

\section{j. Android Studio}

Android Studio adalah suatu program aplikasi yang digunakan untuk membantu para programmer dalam membuat aplikasi berbasis android berdasarkan Intellij IDEA (Developers, 2018).

k. Laravel

Laravel adalah salah satu framework PHP yang dibangun dengan konsep MVC (Model View Controller). Laravel dirancang untuk meningkatkan kualitas perangkat lunak dengan menyediakan sintaks yang mudah, jelas, dan menghemat waktu.

I. PHP

PHP adalah bahasa pemrograman server-side scripting yang menyatu dengan bahasa pemrogram web HTML untuk membuat halaman web yang dinamis. Maksud dari serverside scripting adalah sintaks dan perintah-perintah yang diberikan akan sepenuhnya dijalankan di server tetapi disertakan pada dokumen HTML. Ketika seorang pengguna internet akan membuka suatu situs yang menggunakan fasilitas server-side scripting PHP, maka terlebih dahulu server yang bersangkutan akan memproses format HTML ke webbrowser pengguna internet tadi (Sunarfrihantono, 2003).

\section{m. MySQL}

MySQL adalah sebuah program yang digunakan untuk membuat database (database server) yang berada di bawah Lisensi GNU/GPL (General Public License) yang mampu menerima dan mengirimkan datanya dengan sangat cepat, multi user serta menggunakan perintah standar SQL (Structured Query Language) (Nugroho, 2015).

\section{Metode Penelitian}

\section{a. Pengumpulan dan Pengolahan Data}

Data dalam penelitian ini berupa data spasial dan data nonspasial. Data spasial berupa citra GeoEye (Satelit Pengamat Bumi) Puskesmas Paninggaran Tahun 2021 beserta batas desa di kecamatan Paninggaran dan titik koordinat lokasi tempat tinggal Penderita 
90 JURNAL INFOKAM Vol. XVII, No. 2, September 2021

Tuberkulosis di sekitar kecamatan Paninggaran yang didapatkan mengunakan paket software leafletjs dan Goggle Maps. Data nonspasial berupa data jumlah kasus Tuberkulosis di kecamatan Paninggaran melalui aplikasi puskesmas dan petugas terkait dari data tahun 2020 - 2021 dalam bentuk data tabular/tabel. Data yang digunakan untuk penelitian ini adalah data kasus Tuberkulosis dengan penderita baru.

Data terbaru kasus Tuberkulolis di wilayah kerja Puskesmas Paninggaran Tahun 2020 sampai dengan 2021 Bulan Juni sendiri ditemukan angka kasus sebagai berikut:



Gambar 1. Kasus Tuberkulosis Paninggaran Th. 2020

\begin{tabular}{|c|c|c|c|c|c|c|c|c|}
\hline \multicolumn{9}{|c|}{ DATA PASIEN TUBERKULOSIS TAHUN 2021} \\
\hline NO/BULAN & NAMA & NIK & ALAMAT & JENIS KELAMIN & USIA & $\begin{array}{l}\text { TANGGAL AWAL } \\
\text { PENGOBATAN }\end{array}$ & $\begin{array}{c}\text { ANGKA } \\
\text { KASUS } \\
2021\end{array}$ & \\
\hline \multicolumn{7}{|l|}{ JANUARI } & JANUARI & 3 \\
\hline 1 & IMRON & & NOTOGIWANG & LAKI-LAKI & 54 & 07 JANUARI 2021 & FEBRUARI & - \\
\hline 2 & TURAH & & TANGGERAN & PEREMPUAN & 66 & 12 JANUARI 2021 & MARET & 1 \\
\hline 3 & KHUMASI & & DOMIYANG & PEREMPUAN & 52 & 21 JANUARI 2021 & APRIL & - \\
\hline \multicolumn{7}{|l|}{\begin{tabular}{|l|} 
FEBRUARI \\
\end{tabular}} & MEI & 4 \\
\hline & - & & & & & & JUNI & 2 \\
\hline \multicolumn{7}{|l|}{ MARET } & JULI & \\
\hline 1 & M.AFKAR.R & & & LAKI-LAKI & 3 & 01 MARET 2021 & JUMLAH & 10 \\
\hline \multicolumn{9}{|l|}{ APRIL } \\
\hline 1 & - & & & & & & & \\
\hline \multicolumn{9}{|l|}{ MEI } \\
\hline 1 & M.DEVANO.R & & SAWANGAN & LAKI-LAKI & 2 & 03 MEI 2021 & & \\
\hline 2 & ZULI TRIYANTO & & DOMIYANG & LAKI-LAKI & 27 & 05 MEI 2021 & & \\
\hline 3 & AMINUDIN & & PANINGGARAN & LAKI-LAKI & 21 & 18 MEI 2021 & & \\
\hline 4 & MABRURI & & WERDI & \begin{tabular}{|l|} 
LAKI-LAKI \\
\end{tabular} & 39 & 22 MEI 2021 & & \\
\hline \multicolumn{9}{|l|}{ JUNI } \\
\hline 1 & MARDOTILAH & & KRANDEGAN & PEREMPUAN & 23 & 21 JUNI 2021 & & \\
\hline 2 & ABDUL MUKMIN & & MADENDO & LAKI-LAKI & 23 & 30 JUNI 2021 & & \\
\hline JULI & & & & & & & & \\
\hline
\end{tabular}

Gambar 2. Kasus Tuberkulosis Th. 2021

Perkembangan kasus Tuberkulosis di wilayah Kecamatan Paninggaran sendiri memerlukan perhatian dari pemerintah dan dinas kesehatan terkait, supaya bisa menurunkan angka persebaran Tuberkulosis di masyarakat. Oleh sebab itu, penulis mencoba membuat sebuah Sistem Informasi Geografis Sebaran Penyakit Tuberkulosis berbasis Android dengan menu-menu yang bermanfaat bagi masyarakat luas serta mudah digunakan, dengan maksud sebagai dasar mendapatkan informasi pemetaan daerah sebaran penyakit Tuberkulosis di wilayah kerja Puskesmas Paninggaran. Selain itu, akan ada fitur-fitur yang akan dibangun seperti menu jumlah kasus sebaran pasien Tuberkulosis, menu peta sebaran pasien Tuberkulosis, menu peta lokasi pasien Tuberkulosis dan menu berita edukasi tentang penyakit Tuberkulois, sehingga masyarakat akan lebih mudah dalam melihat dan mencari informasi diantaranya, informasi jumlah angka kasus Tuberkulosis, informasi peta jumlah sebaran, informasi peta lokasi pasien dan berita edukasi mengenai 
penyakit Tuberkulosis. Selain itu Sistem Informasi Geografis ini nantinya akan berguna untuk Dinas Kesehatan khususnya Kecamatan Paninggaran dan Puskesmas Paninggaran dimana petugas puskesmas sebagai adminya dalam proses input data pasien secara digital, sehingga proses pendataan dapat lebih efisien serta masyarakat umum dapat mengetahui jumlah angka Tuberkulosis, peta sebaran kasus Tuberkulosis, melihat lokasi tempat tinggal pasien dan berita edukasi kesehatan dengan mudah.

Pengolahan data meliputi data spasial peta digital kecamatan Paninggaran beserta batas-batas desa Kecamatan Paninggaran dan data nonspasial kasus Tuberkulosis akan diolah menggunakan basis data Android Studio, Laravel, php, Sql, XXAMP, Java dan Situs Online Leafletjs.com.

\section{b. Tahapan Penelitian}

Tahapan penelitian kami merujuk pada metode Waterfall, yaitu :

1. Requirement

Requirement yaitu mempersiapkan dan menganalisa kebutuhan dari software yang akan dikerjakan. Informasi dan insight kami peroleh dari hasil wawancara atau diskusi dengan petugas di puskesmas kecamatan paninggaran yang menangani Tuberkulosis atau tokoh masyarakat yang ada di desa-desa di Kecamatan Paninggaran, survei atau observasi ke lokasi di desa-desa yang ada di kecamatan paninggaran yang terdapat kasus turbekulosisnya, studi literatur dengan mengakses website data.pekalongankab.go.id, serta buku dan jurnal yang terkait. Adapun data yang didapatkan sudah dijelaskan pada point sebelumnya yaitu pengumpulan dan pengolahan data.

2. Design

Setelah tahapan requirement selanjutnya kita ke tahapan design rancangan sistem atau aplikasinya dengan membuat Flowchart sistem, DFD, ERD dan rancangan tabel-tabel yang dibutuhkan.

3. Implementation

Langkah selanjutnya setelah mendesign rancangan sistemnya, adalah menerapkan kedalam source code program. Dalam penelitian ini kami menggunakan bantuan program android studio untuk merancang aplikasi adroidnya (user interface), Framework Larave/ sebagai tampilan BackOfficenya dengan menggunakan bahasa pemrograman PHP dan MySQL untuk databasenya.

4. Integration \& Testing

Berikutnya setelah implementation adalah melakukan proses integrasi dan pengujian sistem. Pada tahap ini, akan dilakukan penggabungan modul yang sudah dibuat pada tahap sebelumnya. Setelah proses integrasi sistem telah selesai, berikutnya masuk pada pengujian modul. Tujuan pada tahapan ini adalah untuk mengetahui apakah perangkat lunak sudah sesuai dengan desain, dan fungsionalitas dari aplikasi apakah berjalan dengan baik atau tidak. Jadi, dengan adanya tahap pengujian, maka dapat mencegah terjadinya kesalahan, bug, atau error pada program.

5. Operation \& Maintenance

Setelah dilakukan pengujian sistem, maka akan masuk pada tahap pemakaian perangkat lunak oleh pengguna (user). Untuk proses pemeliharaan, memungkinkan pengembang untuk melakukan perbaikan terhadap kesalahan yang ditemukan pada aplikasi setelah digunakan oleh user.

\section{c. Design atau Perancangan Sistem}

Perancangan sistem dilakukan untuk memberikan gambaran, perencanaan, dan pembuatan sketsa pengaliran suatu data dalam program. Sehingga memudahkan seseorang dalam pembuatan sistem agar sistem dapat dengan mudah dimengerti oleh orang yang menggunakan sistem tersebut.

Demi meningkatkan kinerja sistem informasi peta persebaran penyakit Tuberkulosis, maka pada perancangan yang diusulkan sistem informasi peta persebaran Tuberkulosis ini dapat dilakukan menggunakan aplikasi mobile Android, sehingga masyarakat yang membutuhkan dapat dengan mudah menemukan data yang ada di Puskesmas Paninggaran dengan cepat, tepat, dan tertata.

Adapun alur sistem informasi yang diusulkan di Puskesmas Paninggaran menggunakan aplikasi online berbasis Android yaitu sebagai berikut : 


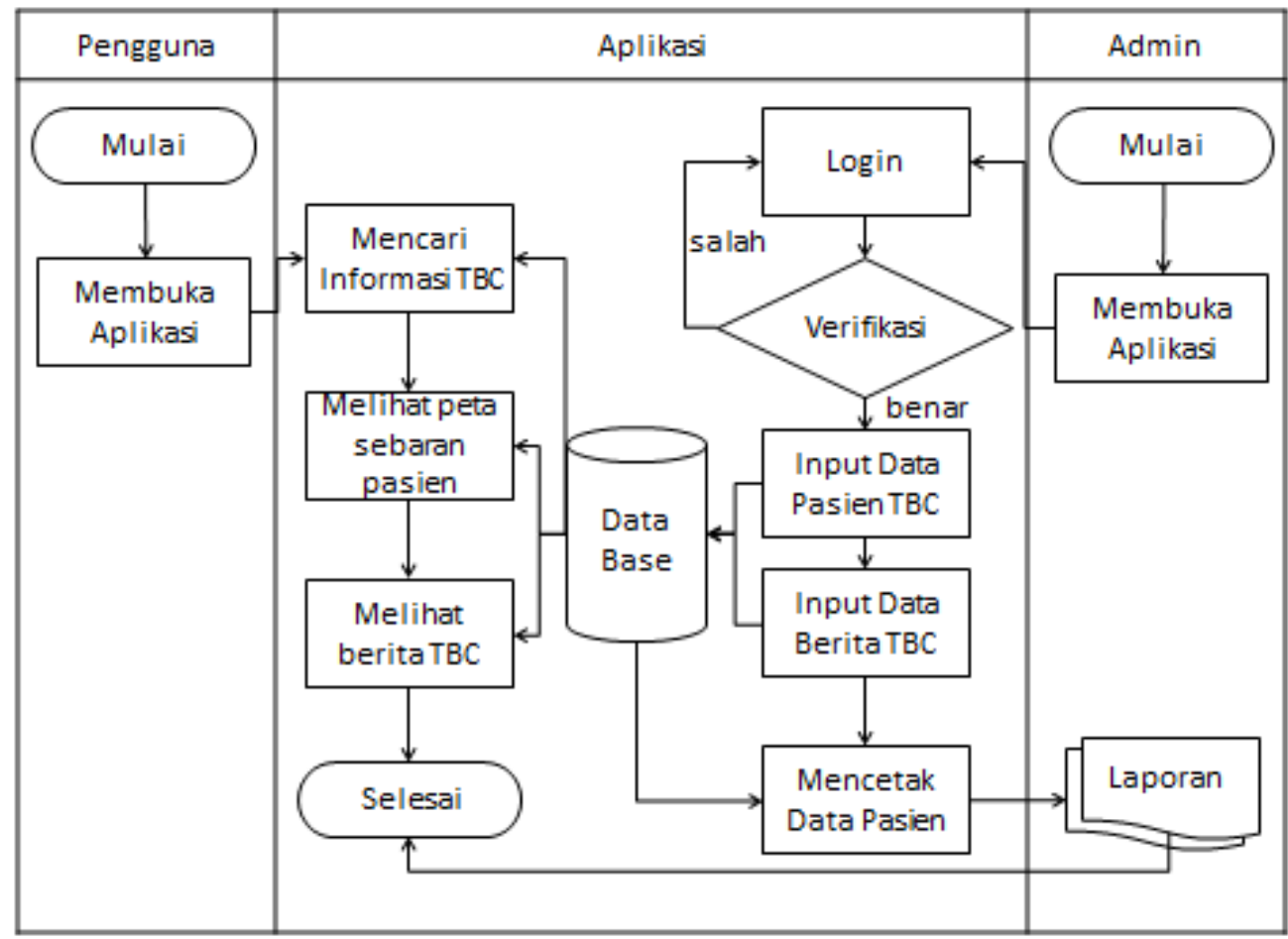

Gambar 3 Flowchart Sistem yang Diusulkan

Dari gambar 3 Flowchart Sistem yang diusulkan diatas menjelaskan tahapan pengguna aplikasi dalam mencari informasi persebaran Tuberkulosis, pertama Admin melakukan login, terverifikasi jika benar admin dapat menginput data pasien Tuberkulosis yang kemudian tersimpan di database sampai mencetak laporan berupa data pasien, kedua dari pengguna aplikasi membuka aplikasi kemudian pengguna bisa mencari informasi Tuberkulosis, melihat peta persebaran Tuberkulosis serta melihat berita Tuberkulosis yang diinput oleh pihak Admin dan proses selesai.

Perancangan Aliran Data

Dalam merancang aliran sistem informasi ini diperlukan alat bantu untuk menggambarkan proses-proses yang ada dan aliran data apa saja yang masuk dan keluar dari proses tersebut, yaitu dengan menggunakan DFD (Data Flow Diagram). Diagram Konteks sistem informasi persebaran Tuberkulosis di Puskesmas Paninggaran dapat digambarkan sebagai berikut :



Gambar 4. Diagram Konteks

Dari gambar 4. Diagram Konteks diatas terdapat 1 proses yaitu Sistem Informasi Persebaran Tuberkulosis di Puskesmas Paninggaran, dan 2 entitas (Admin dan Pengguna). Admin disini login terlebih dahulu kemudian meng-input data pasien TBC dan data Berita TBC kedalam sistem. Pengguna mencari informasi dari sistem kemudian menerima info peta sebaran pasien TBC dan berita TBC dari sistem. 


\section{Hasil Penelitian dan Pembahasan}

a. Gambaran Umum Responden

Responden yang kami wawancarai dan ambil datanya adalah dokter, perawat dan petugas di puskesmas Kecamatan Paninggaran. Puskesmas Paninggaran merupakan salah satu Puskesmas di Kabupaten Pekalongan yang berlokasi di Jalan Raya Paninggaran. Wilayah kerja Puskesmas Paninggaran Kabupaten Pekalongan meliputi seluruh wilayah Kecamatan Paninggaran. Sarana kesehatan yang ada di wilayah kerja Puskesmas Paninggaran adalah Puskesmas Induk, 1 Puskesmas Rawat Jalan, 1 Puskesmas Rawat Inap, 15 Poliklinik Kesehatan Desa, 76 Posyandu, 3 unit mobil Pusling dan 10 unit sepeda motor. Adapun jumlah dokter yang ada sebanyak 2 orang dokter umum dan seorang dokter gigi serta 12 orang Perawat dan 26 Bidan.

\section{b. Hasil Tampilan Sistem}

1. Tampilan Halaman Beranda

Halaman ini merupakan halaman awal ketika masyarakat membuka aplikasi. Untuk melihat jumlah kasus, peta sebaran, peta lokasi, berita TB, tentang aplikasi dan tombol keluar alpikasi.



Gambar 5. Tampilan Halaman Beranda atau Awal

2. Tampilan Halaman Peta Sebaran

Halaman Peta Sebaran digunakan untuk menampilkan informasi-jumlah kasus dari masing-masing desa dalam bentuk peta. 


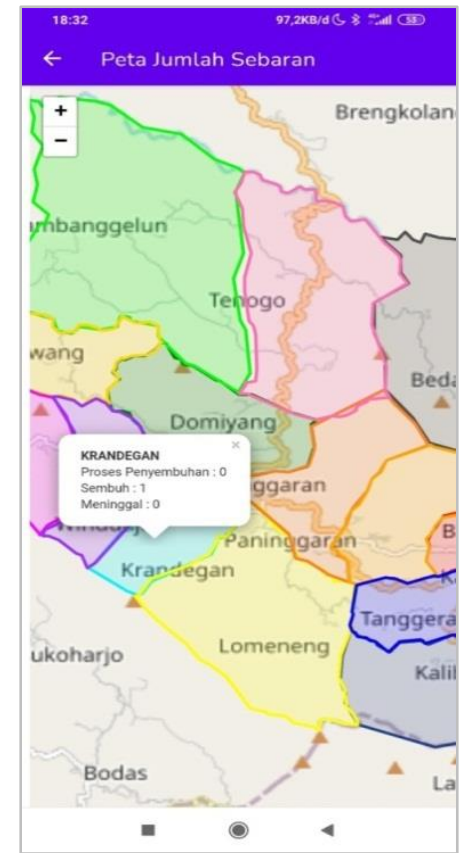

Gambar 6. Tampilan Halaman Peta Sebaran

3. Tampilan Halaman Informasi Lokasi Pasien

Halaman ini digunakan untuk menampilkan lokasi pasien TB.



Gambar 7. Tampilan Halaman Peta Lokasi

4. Tampilan Halaman Berita TB

Halaman Berita TB digunakan untuk menampilkan dan melihat informasi berita edukasi penyakit TB. 


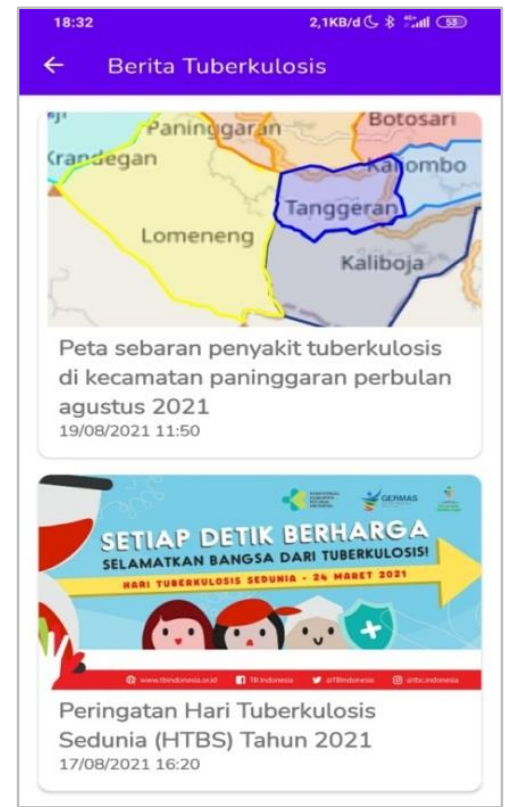

Gambar 8. Tampilan Halaman Retribusi

5. Tampilan Halaman Login Web

Digunakan untuk masuk kedalam aplikasi dengan menginputkan username dan password di text box yang ada.



Gambar 9. Tampilan Halaman Login Web

6. Tampilan Halaman Dashboard

Digunakan untuk menampilkan Jumlah desa, pasien, berita, admin serta untuk menginput data desa, pasien, berita, cetak laporan dan informasi admin.

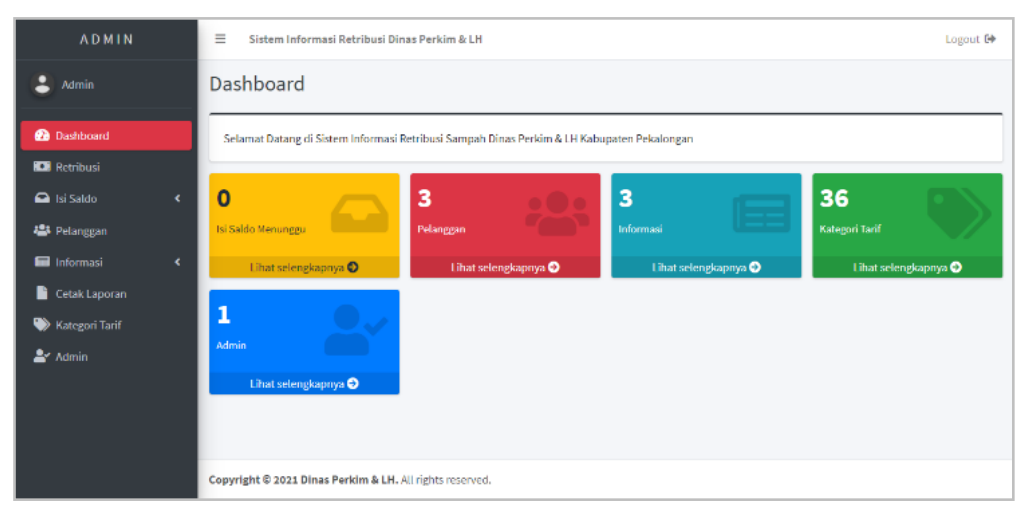

Gambar 10. Tampilan Halaman Dashboard 


\section{Kesimpulan dan Saran}

\section{a. Kesimpulan}

Kesimpulan yang dapat diambil dari pembahasan di atas yaitu Sistem informasi persebaran TB di Puskesmas Paninggaran terdiri dari aplikasi Android untuk masyarakat dan aplikasi website untuk administrator. Aplikasi Android berisi menu informasi jumlah kasus dan persebaran pasien TB di Kecamatan Paninggaran, serta berita-berita seputar penyakit TB. Aplikasi website berisi menu untuk mengelola data pasien TB, mengelola data berita TB, mencetak laporan jumlah kasus, serta mengelola akun admin. Dengan adanya aplikasi ini masyarakat dapat dengan mudah melihat persebaran pasien TB di Kecamatan Paninggaran serta mendapat berita tentang TB dari lokasi manapun dan kapanpun smartphone dengan jaringan internet.

\section{b. Saran}

Adapun saran yang kami berikan adalah Penelitian ini dapat dijadikan referensi untuk penelitian selanjutnya di bidang sistem informasi retribusi. Penambahan dan pengembangan fitur aplikasi sangat dimungkinkan seiring dengan berkembangnya teknologi kedepannya. Penulis mengharapkan pada pengembangan aplikasi berikutnya agar terdapat fitur lapor tetangga jika ada keluhan yang menyerupai TB.

\section{Daftar Pustaka}

Amsyah, Z., 2001. Manajemen Sistem Informasi. Jakarta: Gramedia Pustaka.

Bekti, 2015. Pengertian Website. [Online] Available at: https://repository.bsi.ac.id/index.php/unduh/item/1598/File_10-BAB-II-Landasan-Teori.pdf

Daniati;, 2021. https://tbindonesia.or.id/berita/launchingperprestbc/. [Online] Available at: https://tbindonesia.or.id/berita/launchingperprestbc/

Developers, G., 2018. Mengenal Android Studio. [Online] Available at: https://developer.android.com/studio/intro/ [Diakses 1 Agustus 2018].

Ferry Anggriawan Susanto, C. S., 2015. Identifikasi Daging Sapi Dan Daging Babi Menggunakan Fitur Ekstraksi Grey Level Co-Occurrence Matrix Dan K-Nearest Neighbor Classifier.

Kadir \& Triwahyun, 2013. [Online] Available at: https://repository.bsi.ac.id/index.php/unduh/item/92430/File_10-BAB-II-LandasanTeori.pdf

Nugroho, 2015. [Online] Available at: http://repository.unissula.ac.id/1855/4/Daftar\%20Pustaka.pdf

Nugroho, A., 2011. Perancangan dan Implementasi Sistem Basis Data. Yogyakarta: ANDI.

Prahasta, E., 2002. Konsep-konsep Dasar Sistem Informasi Geografis. Bandung: Informatika Bandung.

Sunarfrihantono, 2003. [Online] Available at: http://eprints.polsri.ac.id/3616/7/7.\%20Daftar\%20Pustaka.pdf

Susanto, 2018. Remastering Sistem Operasi Android Untuk Peningkatan Performa Pada Lenovo A6000 Plus. Jurnal Sistem dan Teknologi Infor, p. 12.

Sutabri, Tata, 2012. Analisis Sistem Informasi. Yogyakarta: ANDI.

Yusro, 2013. Pengertian Google Maps API. [Online] Available at: http://www.myusro.info/2013/02/pengertian-google-maps-api.html [Accessed 1 Agustus 2018]. 